OAK RIDGE NATIONAL LABORATORY

LOCKHEED WATTIN
RECEW: JUN 211996

OSTI

The Principles of Life-Cycle Analysis

Lawrence J. Hill

Donald B. Hunsaker

T. Randall Curlee 
This report has been reproduced directly from the best available copy.

Available to DOE and DOE contractors from the Office of Scientific and Technical Information, P.O. Box 62, Oak Ridge, TN 37831; prices available from (423) 576-8401, FTS 626-8401.

Available to the public from the National Technical Information Service, U.S. Department of Commerce, 5285 Port Royal Rd., Springfield, VA 22161.

This report was prepared as an account of work sponsored by an egency of the United States Government. Neither the United States Government nor any agency thereof, nor any of their employees, makes any warranty, express or implied, or assumes any legal liability or responsibility for the accuracy, completeness, or usefulness of any intormation, apparatus, product, or process disclosed, or represents that its use would not infringe privately owned rights. Reference herein to any specific commercial product, process, or service by trade name, trademark, manufacturer, or otherwise, does not necessarily constitute or imply its endorsement, recommendation, or favoring by the United States Government or any agency thereof. The views and opinions of authors expressed herein do not necessarily state or reflect those of the United States Government or any agency thereof. 


\section{DISCLAIMER}

Portions of this document may be illegible in electronic image products. Images are produced from the best available original document. 


\title{
The Principles of Life-Cycle Analysis
}

\author{
Lawrence J. Hill \\ Energy Division \\ Donald B. Hunsaker \\ Environmental Sciences Division \\ T. Randall Curlee \\ Energy Division
}

May 1996

OAK RIDGE NATIONAL LABORATORY

Oak Ridge, Tennessee 37831

Managed by

LOCKHEED MARTIN ENERGY RESEARCH CORP.

for the

U.S. DEPARTMENT OF ENERGY

under Contract No. DE-AC05-96OR22464 



\section{CONTENTS}

ABSTRACT $\ldots \ldots \ldots \ldots \ldots \ldots \ldots \ldots \ldots \ldots \ldots \ldots \ldots \ldots \ldots \ldots \ldots \ldots \ldots \ldots \ldots$

1. WHAT IS LIFE-CYCLE ANALYSIS? $\ldots \ldots \ldots \ldots \ldots \ldots \ldots \ldots \ldots \ldots \ldots$

2. BENEFIT AND COST CATEGORIES IN LIFE-CYCLE ANALYSIS $\ldots \ldots \ldots \ldots$

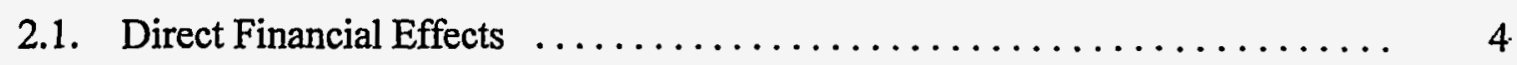

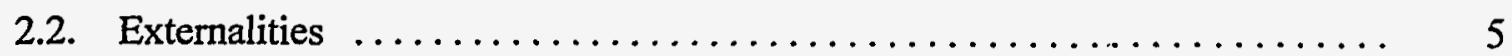

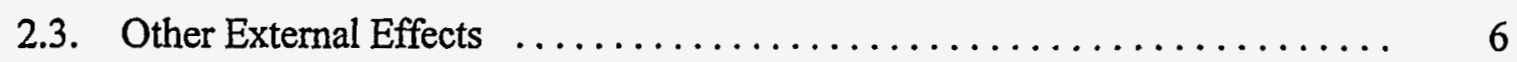

3. ESTIMATING METHODOLOGIES $\ldots \ldots \ldots \ldots \ldots \ldots \ldots \ldots \ldots \ldots \ldots$

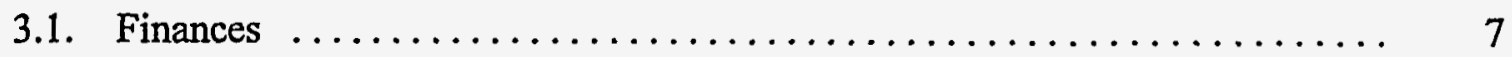

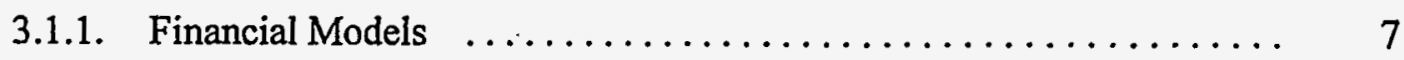

3.1.2. Production-Cost Models $\ldots \ldots \ldots \ldots \ldots \ldots \ldots \ldots \ldots \ldots \ldots \ldots$

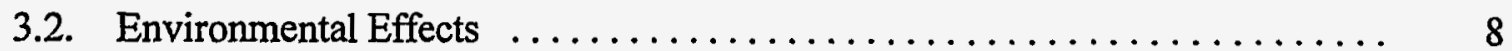

3.2.1. Qualitative Methods $\ldots \ldots \ldots \ldots \ldots \ldots \ldots \ldots \ldots \ldots \ldots \ldots$

3.2.2. Quantitative Methods $\ldots \ldots \ldots \ldots \ldots \ldots \ldots \ldots \ldots \ldots . \ldots \ldots$

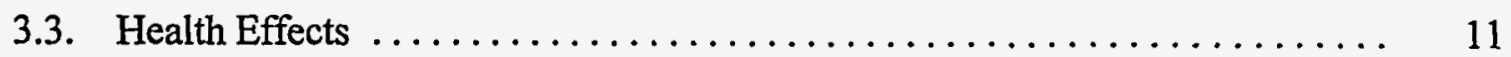

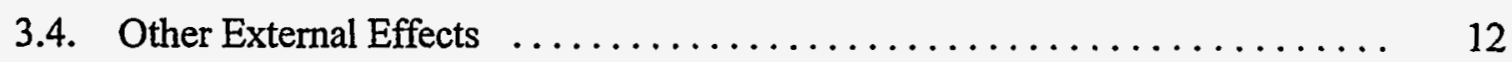

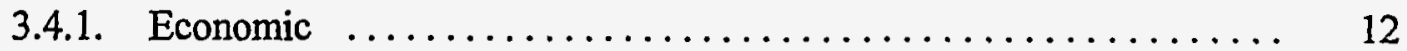

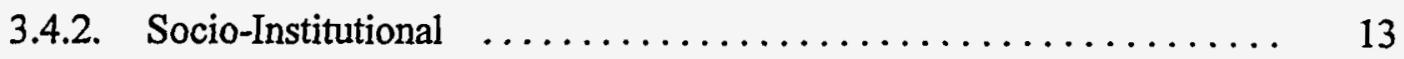

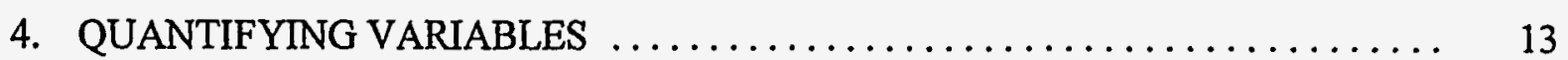

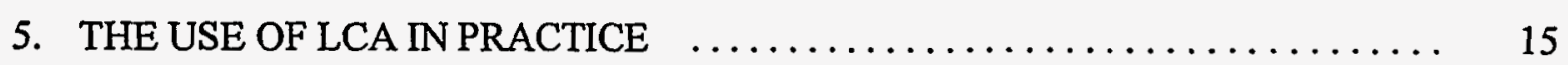

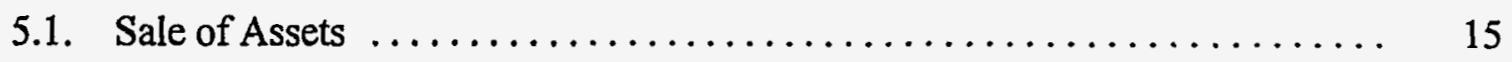

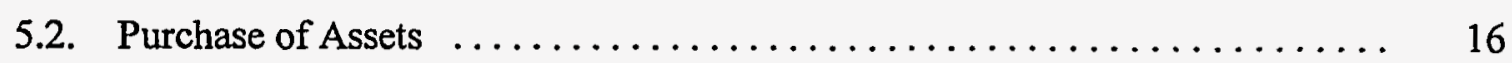

5.3. Damage Assessment ............................. 17

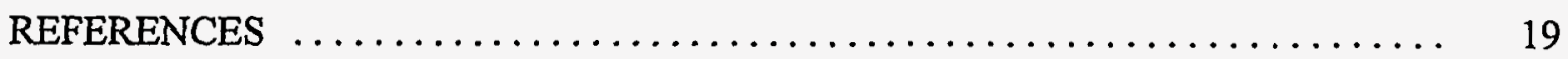




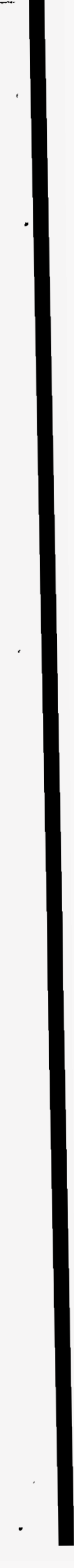




\begin{abstract}
Decisionmakers representing government agencies must balance competing objectives when deciding on the purchase and sale of assets. The goal in all cases should be to make prudent or financially "cost-effective" decisions. That is, the revenues from the purchase or sale of assets should exceed any out-of-pocket costs to obtain the revenues. However, effects external to these financial considerations such as promoting environmental quality, creating or maintaining jobs, and abiding by existing regulations should also be considered in the decisionmaking process. In this paper, we outline the principles of life-cycle analysis (LCA), a framework that allows decisionmakers to make informed, balanced choices over the period of time affected by the decision, taking into account important external effects.
\end{abstract}

Specifically, LCA contains three levels of analysis for any option:

- direct financial benefits (revenues) and out-of-pocket costs for a course of action;

- environmental and health consequences of a decision; and

- other economic and socio-institutional effects.

Because some of the components of LCA are difficult to value in monetary terms, the outcome of the LCA process is not generally a yes-no answer. However, the framework allows the decisionmaker to at least qualitatively consider all relevant factors in analyzing options, promoting sound decisionmaking in the process. 


\section{WHAT IS LIFE-CYCLE ANALYSIS?}

Life-cycle analysis (LCA) is the process of (1) disaggregating various categories of economic benefits and costs resulting from a course of action over the entire period of time affected by the action, (2) quantifying those benefits and costs where possible, and (3) providing results that promote sound decisionmaking. LCA is a tool for decisionmakers to examine systematically all of the effects of their decisions. It is a process, not a methodology. That is, the principles of LCA allow decisionmakers to analyze the effects of their decisions in a consistent way, rather than indicating a method to quantify factors involved in decisionmaking.

"Life-cycle analysis" appears in the literature under different names--and oftentimes with interpretations different from what we use here. "Integrated assessment," "energy-economicenvironmental analysis," "integrated resource planning," and "life-cycle assessment" are four examples. We distinguish our LCA approach from others as an economic decisionmaking tool that includes all of the relevant factors that should be considered by representatives of government in making sound decisions. Our approach encompasses financial effects, environmental stewardship, health, and other economic effects.

Other decisionmaking frameworks are much more limited in scope. To a financial manager, for example, LCA oftentimes exclusively addresses the revenues and out-of-pocket expenditures for a product or process. For example, in its Technical Assessment Guide to show the proper way to evaluate the cost-effectiveness of different electric-generating technologies, the Electric Power Research Institute (1991) says:

The ... methodology includes all the elements of a utility's cost of service, including fuel, operating and maintenance expenses, depreciation, taxes, interest, and net income. Application of the ... method involves projecting these costs over the useful life of an investment.

Because the Technical Assessment Guide approaches decisionmaking from a financial perspective in analyzing investment options, environmental and other effects are not included in the decisionmaking process.

To an environmental manager, LCA oftentimes means an examination of the environmental effects of a decision. For example, the Society of Environmental Toxicology and Chemistry (SETAC) defines "life-cycle assessment" as follows (SETAC, 1991):

The life-cycle assessment is an objective process to evaluate the environmental 
burdens associated with a product, process, or activity by identifying and quantifying energy and material usage and environmental releases, to assess the impact of those energy and material uses and releases on the environment, and to evaluate and implement opportunities to effect environmental improvements. The assessment includes the entire life cycle of the product, process, or activity, encompassing extracting and processing raw materials; manufacturing, transportation, and distribution; use/re-use/maintenance; recycling; and final disposal. (Emphasis supplied.)

Viewpoints other than environmental or financial ones also limit these types of assessments. To an energy manager, for example, LCA typically refers to the flow of energy in a process or system. Again, LCA as used here, encompasses all of these effects.

In applying the principles of LCA, a course of action is sound when its benefits over the years affected by the decision exceed its costs. Further, a decision on one course of action is better (i.e., more cost-effective) than a decision on another if its ratio of benefits to costs is greater than the other course of action.

The principles of LCA are often applied to asset-purchase decisions. Typically, an array of assets are compared, and the most cost-effective are chosen for purchase. The principles of LCA can also be used to analyze the sale of assets. Although the principles are the same, the analysis may be complicated by different sales options. For example, options to sell an asset outright may have alternatives which involve retrofitting the asset. In this case, the investment in retrofitting must be included as part of the LCA.

The principles of LCA can be applied to other analyses besides buy-sell decisions. The principles can also be used in damage assessments. In this case, the financial, environmental, health, and other effects of natural or man-made disasters are considered. For example, the principles of LCA were used in analyzing the effects of Hurricane Hugo in Charleston, South Carolina in 1989.

Perspective is an important consideration in estimating cost-effectiveness using LCA. That is, from what perspective are costs and benefits measured? The results can vary dramatically depending on the viewpoint from which benefits and costs are measured.

Consider the decisionmaking process of an electric utility in constructing electric-generating capacity, for example. The utility typically can choose from among different types of generating technologies to satisfy its capacity requirements. These options have various levels of environmentally harmful emissions associated with them, causing damage to local, regional, and international environments. They also may have different effects on local and regional labor 
markets. Assuming that the utility does not have to pay for these harmful emissions or does not care about the effects of its decisions on local labor markets, its decision on what type of power plant to build will be based strictly on the expected revenues (benefits) and out-of-pocket expenditures (costs) of constructing and running the power plants. If the present value of the revenues exceeds the costs, the power plant is "cost-effective" from the standpoint of the utility. The more that benefits exceed costs, the more attractive the plant is to the utility. From the utility's perspective, cost-effectiveness is based on private considerations.

If the cost-effectiveness of the generating plants was measured from the standpoint of the general public at the national level, however, a different result may be obtained. In this case, the additional costs of damage to the environment would be included in estimating cost-effectiveness. Many would argue that differences in employment among the options should not be considered at the national level because they are simply transfers from one labor market to another.

However, suppose a state conducted the analysis and cost-effectiveness of the generating plants is then measured from the state perspective. In this case, any net change in jobs in the state as a result of constructing a plant could correctly be included in the analysis. This state-level analysis is a social one, albeit from a narrower perspective than the one conducted from the national perspective.

We illustrate the differences between private and social analyses in Figure 1. From the private perspective, an individual or firm makes a decision and reaps some proceeds and incurs some costs. A rational decision can be arrived at in comparing the proceeds and costs. The private benefits and costs are included in the public perspective, but there are also external effects. Besides the environmental effects just discussed, there could be some health costs as well. In addition to these economic "externalities," there could also be other economic and,socio-institutional effects.

In most cases, the difficulty of conducting a broader, social analysis is quantifying some of the variables. It is relatively easy to quantify the benefits and costs in a private, financial analysis. The benefits and costs are the expected revenues and expenses, respectively. Many of the external effects shown in Figure 1, however, are very difficult to quantify, and in some cases, impossible. In the latter case, the decisionmaker must use his judgment in addition to looking at the values of variables that can be quantified.

In the following sections, we build on this overview of LCA. In the next section, we discuss the categories of benefits and costs to be included in LCA in much greater detail. In Section 3, we discuss methodologies that are commonly employed to estimate the direct financial effects using the principles of LCA, and the more difficult-to-quantify external effects. In Section 4, we discuss measurement problems, distinguishing between placing values on goods traded in markets and those 
that are not traded in markets. In the final section, we give three examples of how LCA can be used in practice.

Figure 1

The Life-Cycle Analysis Process

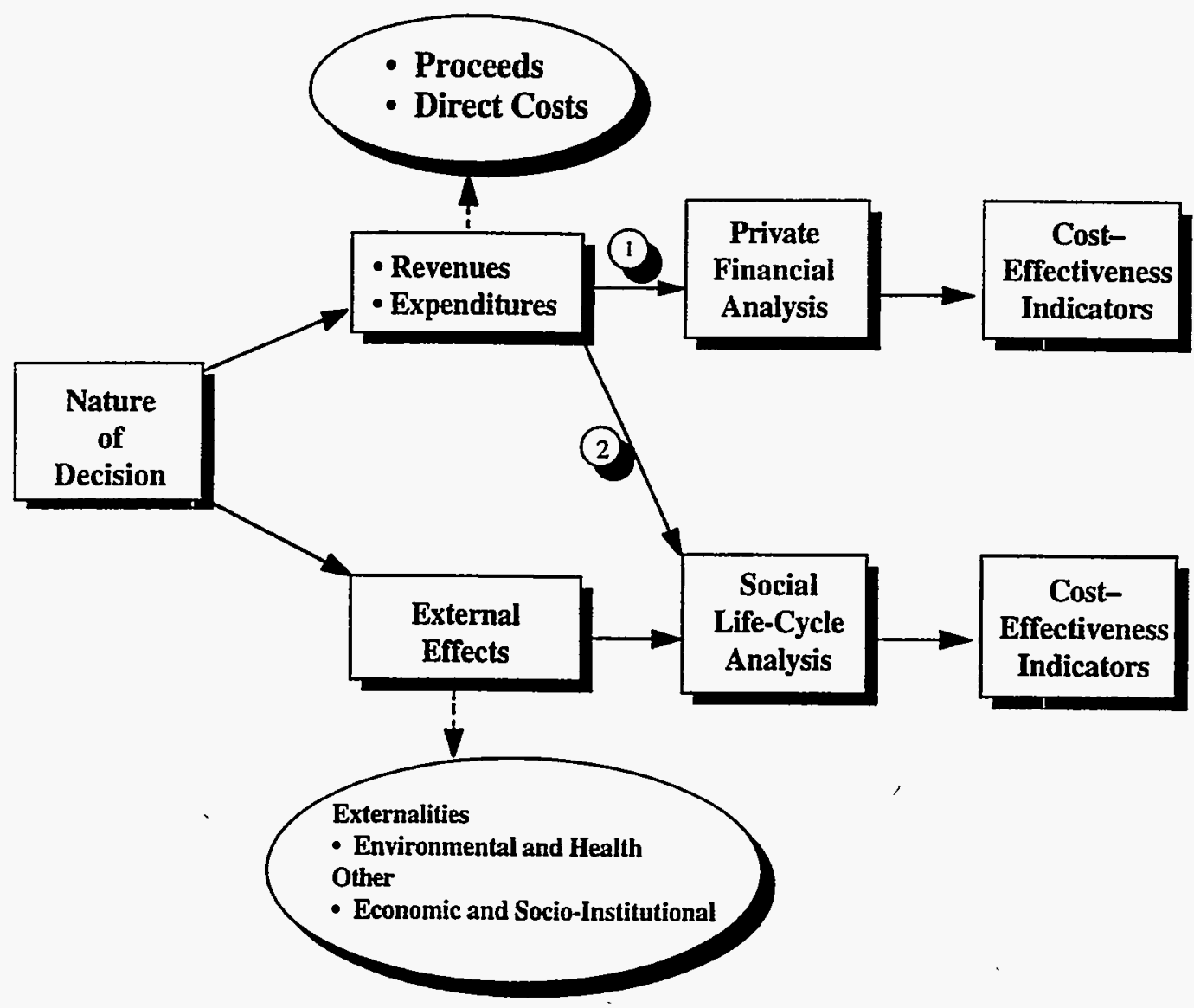

2. BENEFIT AND COST CATEGORIES IN LIFE-CYCLE ANALYSIS

\subsection{Direct Financial Effects}

A decision to buy or sell assets must consider the (1) revenues or proceeds from the sale and 
(2) the costs or amount expended to ready the assets for sale. An important consideration related to revenues is the value placed on the asset--i.e., the selling price of the asset. In private business transactions, there is a distinction between the book value of assets (purchase cost net of accumulated depreciation) and their replacement or market value. Because of differences in accounting for capital goods in the public sector, the more appropriate valuation may be replacement or market value. The value of some government assets may be difficult to determine because the assets were constructed for the government's exclusive use, with limited substitution possibilities in the private sector. For these assets, their only value may be as scrap.

The costs are any out-of-pocket expenditures to ready the assets for sale or disposition. They include any refurbishing expenditures, retrofitting expenditures, sales-related costs, and transactions costs. The latter may be crucial for government assets because the GSA process may be prohibitively expensive for some asset categories. In that case, it may be more cost-effective to sell these types of assets for scrap.

\subsection{Externalities}

Depending on the nature of the transaction, there are varying degrees of benefits and costs external to the revenues and out-of-pocket expenditures in transactions involving government assets. In technical terms, some of these effects may be "externalities."

An externality refers to a situation in which an economic entity imposes costs or benefits on another entity without including those costs and benefits in its determination of cost-effectiveness. Externalities can be positive or negative: they can impose benefits or costs on others. The pollution emitted from an electric-generating plant is an example of an external cost if the firm generating the electricity is not financially accountable for damage the plant causes to the environment. On the other hand, a landowner, planting trees to improve the quality of his or her property, can also generate external benefits for others by reducing erosion, increasing air quality, and improving aesthetics in his or her neighborhood.

Externalities are one type of market failure in an economy. A market failure is the inability of a market to allocate resources efficiently because of imperfections in the market. Besides externalities, market failures include (1) the ability of one or more firms to exert market power in some industries; (2) the existence of public or social goods; and (3) imperfect information for both consumers and producers in some industries. In Figure 1, we place externalities in two categories:

Environmental Effects. These are the air, water, ecological, land-use, and solid-waste effects resulting from the purchase (and use) or sale of assets. These effects can be local, regional, or global in scope.

Health Effects. The use of an asset or its readying for sale may affect the safety and health 
of employees or the surrounding community, depending on the asset's future use.

\subsection{Other External Effects}

There are other effects external to the direct financial transaction that must also be considered in decisionmaking. As discussed below, in certain types of transactions these effects may also be "externalities" in the technical economic sense. From Figure 1, we place these other external effects in two categories:

Economic Effects. Depending on the type of asset considered for purchase or sale, there could be both microeconomic and macroeconomic effects. A "microeconomic" effect refers to the sale's effect on the market for that type of asset (e.g., its price). For example, if a government agency sells its inventory of an asset that it owns a large portion of in the domestic or world market, the sale could significantly affect the price of the asset in this market. "Macroeconomic" effects are those on the general economy as the result of an asset's purchase or disposition. Depending on the type of asset and transaction, these effects could be on the local economy (e.g., employment; income) or more national in scope (e.g., the U.S. trade balance; oil-import vulnerability).

Including these economic effects in the benefit-cost calculus is controversial. Many economists would not consider them externalities and, therefore, not part of the cost-effectiveness calculus. However, many of these external effects are highly visible to the public and must at least be qualitatively considered by public decisionmakers.

Consider the market-price effect for the sale of an asset. Many economists would argue that this is a "pecuniary externality"--not a "real externality"--and should therefore not be included in the benefit-cost calculus. To a public decisionmaker, however, a decision that could result in drastic changes in domestic and international commodity markets may not be wise even if it passes a standard cost-effectiveness test.

Including the creation of jobs as an economic benefit in benefit-cost analysis is also controversial. Many economists would argue that the creation of jobs associated with a construction project, for example, is simply a transfer of a job from another part of the economy. Therefore, they would argue that the net amount of job creation from a national, social perspective is zero. However, the creation of jobs is a highly visible issue to the public and should be considered in the decisionmaking process. Moreover, the argument to exclude the creation of jobs from benefit-cost analysis is less convincing if the economy is not fully employed and a decision to undertake a project creates new jobs in the economy.

Socio-Institutional Effects. Purchasing or disposing of assets in alternative ways could be perceived by the public in different ways. This factor is especially important when making decisions about contaminated materials. Also, different types of local, state, and federal regulations affect 
different options in different ways. This also must be considered by decisionmakers. Some government assets may also have proliferation value. Although difficult to quantify, this effect should be considered qualitatively in the decisionmaking process.

\section{ESTIMATING METHODOLOGIES}

A single model that can be used to estimate all of the financial and external effects in benefitcost analysis does not exist. Therefore, in practice multiple models must be used. In the next pages, we describe the types of tools and models that can be used to estimate financial, environmental, health, and other external effects.

\subsection{Finances}

\subsubsection{Financial Models}

Financial models project the finances of a firm, project, or transaction, given a set of assumptions about the nature of the firm, project, or transaction. The assumptions themselves may be products of other models. For example, the annual price stream used to determine the expected revenues of a project over its useful life may be the output of another model.

Because financial models usually incorporate accounting relationships, their output can usually be shaped to accommodate the needs of the user. Typical outputs of financial models include:

- primary financial statements (income statement, balance sheet, cash flow),

- financial ratios calculated from the primary financial statements, such as return on equity, net present value of a project, plan, or transaction, and benefit-cost ratios.

The Oak Ridge Financial Model (ORFIN) is an example of a financial model (Hadley, 1996). Although it was originally created to simulate the financial performance of electric utilities and electric utility projects, it can easily be adapted to simulate the financial performance of any firm, project, or transaction simply by changing the specification of some equations and input assumptions.

\subsubsection{Production-Cost Models}

A production cost model is an example of a model that could be used to estimate inputs for inclusion in a financial model. A typical production costing model will provide the cost portion of 
the financial benefit-cost calculation over the project years.

Some production cost models are "shells" that allow the user to adapt the model to different industries or processes. For example, FLOW, a process-flow programming tool developed at Oak Ridge National Laboratory (Yuracko, Hadley, and Perlack, 1996), allows users to simulate material flows and material balances in production processes. A financial spreadsheet model calculates costs based on different scenarios assuming various assumptions on the cost of extraction, processing, and waste disposal in a given process.

Other production-cost models are tailored for a specific industry or process. For example, a later version of ORFIN contains an electricity-production costing model (i.e., a load-dispatch model), which will estimate electricity production costs over hours of the day, days of the week, and seasons of the year under different demand and fuel-cost assumptions (Hirst, Hadley, and Baxter, 1996).

\subsection{Environmental Effects}

A variety of methods are available to estimate environmental effects for LCA, ranging from emissions-based inventory compilations to sophisticated transport, fate, effects, and input-output . modeling. This section highlights the major categories of estimating methodologies, their associated strengths and weaknesses, and presents some examples where appropriate.

\subsubsection{Qualitative Methods}

For our purposes here, qualitative approaches are those in which no numeric environmental data or information are used in the evaluation of product or production life cycles. The LCA is done strictly with graphical representations such as pictograms or with binary indicators (e.g., "yes/no") of the potential for adverse environmental impact. In general, advantages of qualitative methods include ease of use, ability to convey information on the environmental aspects of a product's life cycle to a wide audience, and a low to moderate input data intensity. Disadvantages include lack of quantitative output and limited applicability to detailed scientific comparisons.

An example of a qualitative method is the Primary Matrix system (Graedel and Allenby, 1995), in which a matrix is prepared that shows stages of the life cycle of a product (e.g., resource extraction, manufacturing, packaging, transportation, product use, etc.) vs. issues categories relevant to the option under consideration (e.g., manufacturing, environment, toxicity/exposure, or social/political). In the environment matrix, the issues categories would be things such as materials choice, energy use, solid residue, liquid releases, gaseous emissions, etc. Each cell of the matrix is completed with one of three entries: a line through the cell indicates that it is not applicable; a "+" or " ++ " indicates relative degree of environmental benefit; and an oval indicates environmental concern and conveys information about that concern [a shading pattern is used to indicate level of 
concern, and the extent of shading is used to reflect uncertainty in the estimate (completely filled in is $100 \%$ certain, and $25 \%$ filled in is only $25 \%$ certain, etc.)].

A second example of a qualitative method is the checklist, which is straightforward and easy to use. The person conducting the LCA simply answers a series of questions regarding the product or process under evaluation, and compiles a list of characteristics of the entity evaluated. The method does not address degree of impact; either something affects an attribute or it does not. A checklist can be increased in sophistication by allowing the user to answer questions with a numeric score that allows for indicating the degree of impact. For our purposes, this type of checklist would represent a bridge between qualitative and quantitative methods.

\subsubsection{Quantitative Methods}

In our approach to LCA, quantitative methods involve a numeric indication of the nature or extent of a potential environmental impact associated with the life cycle of a product or process. Advantages of quantitative methods include a more scientifically rigorous analysis of impacts and a perception of more thorough analyses. Disadvantages include the high level of expertise needed to conduct the analyses and correctly interpret the results, as well as high data intensiveness. In discussing quantitative methods here, we refer to the enumeration of physical flows. In Section 4, we address the question of placing monetary values on those physical flows.

Inventory Assessment. In this class of approaches, effects are implied from the environmental releases. No actual assessment of environmental consequences is conducted, but considerable effort is devoted to compiling and categorizing environmental releases. In some cases, alternatives are compared in terms of the magnitudes of releases. For example, Product A releases three times as much atmospheric carbon dioxide as Product B. From the standpoint of global warming potential, Product $\mathrm{B}$ is concluded to be more beneficial for the environment, even though the effects of these emissions on global warming were not estimated or quantified with a numerical model. Another characteristic of this approach is that comparisons are made on mass of pollutants without regard to effects or toxicity threshold; for example, emissions of chemical X are assumed to have the same potential for effect as those of chemical Y. This approach is sometimes referred to as "less is best," since it is presumed that the alternative with the fewest environmental loadings per equivalent unit of usage is environmentally preferred.

Effects-Based Inventory Assessment. In this type of assessment, the focus is still on categorizing and quantifying emissions, but the analysis proceeds one step further in terms of weighting the environmental releases based on their potential for effect. For example, emissions of chlorinated hydrocarbons are weighted based on the respective global warming potential of each compound; if compound $\mathrm{X}$ has a global warming potential twice that of compound $\mathrm{Y}$, and equal amounts of $\mathrm{X}$ and $\mathrm{Y}$ are emitted, then weighted emissions for $\mathrm{X}$ are twice that of $\mathrm{Y}$. Comparing the environmental effects of two hypothetical products $A$ and $B$ would be done using weighted emissions of the two compounds. Again, the actual effects of specific emissions on global warming are not assessed, but instead effects are implied from the nature and magnitude of the releases. Other 
examples of this method include the Carnegie Mellon University approach for weighting emissions of the toxic release inventory based on human health effects, and the University of Tennessee approach for weighting toxic release inventory data based on human health and environmental effects.

The "Hazard Ranking" method, which is another technique in this general category, assigns a ranking to the hazards associated with a product, process, or activity. A hazard value such as low, medium, or high is assigned to a particular pollutant based on toxicity, cancer potency, environmental toxicity, or other similar values. The "Hazard Matrix" approach relates the human health or environmental hazard of a particular chemical or pollutant to potential effects based on toxicity or similar data, and uses this relationship to evaluate the hazard without going through a detailed exposure assessment. The toxicity information, together with the quantity of chemical released, would be used to arrive at an overall score for a particular chemical for a particular life cycle stage.

Another example is the critical volume method, in which environmental releases (usually mass per unit time) are divided by environmental standards (usually mass per unit volume) to arrive at a "critical volume." Critical volumes of all air pollutants, for example, would then be added for each of chemicals " $A$ " and " $B$ " in order to form a basis for comparing the environmental effects of the chemicals.

Environmental Consequence Assessment. The Society for Environmental Toxicology and Chemistry (SETAC) and the U.S. Environmental Protection Agency have proposed an LCA method that involves four basic steps: 1) scoping; 2) inventory assessment; 3) impact assessment; and 4) improvement analysis. Methods described above can be considered as stopping at the inventory assessment stage. The SETAC approach is much more comprehensive and incorporates environmental consequence assessment using such tools as transport, fate, and effects modeling and ecological and human health risk assessment. It is very data and expertise intensive, and adds additional time and cost to the LCA. Although the SETAC approach is very comprehensive, it stops at the stage of quantifying an impact to an environmental resource and does not go the extra step of attempting to characterize that impact in monetary terms. Quantifying environmental impacts is the subject of the next section.

Environmental Indices. A fourth type of quantitative approach is to develop numerical indices that reflect the magnitudes of appropriate impacts without conducting the detailed methodological assessments of the SETAC approach. An example is the Environmental Priority System developed by the Swedish Environmental Research Institute and used at Volvo. It involves computation of an environmental load index, which is a numeric value indicating the overall environmental load following the production of a certain quantity of a product or caused by a selected human activity. It represents an evaluation and weighing of the importance of a certain amount of an emitted substance or environmental release. The environmental load index is computed for product $\mathrm{A}$ and product $\mathrm{B}$, and the numeric values are compared. For example, the environmental load value of a composite based front-end of a car is $25.67 \mathrm{ELU}$, and the value of a 
galvanized steel unit of the same component is 40.64. After these numeric values are developed and compared, the final step is to compare them and see if the difference is statistically significant.

Another example of this type of approach is the AT\&T abridged LCA method, which employs a matrix of life cycle stages vs. environmental issues (Graedel, Allenby and Comrie, 1995); the five life cycle stages are premanufacture, product manufacture, product packaging and transport, product use, and refurbishment, recycle, disposal; the five environmental issues are materials choice, energy requirement, solid residues, liquid residues, and gaseous emissions. For a product, process, or facility, integer scores are assigned in each cell ranging from 0 (highest impact on the environment) to 4 (lowest impact on the environment). Because there are 25 cells, a maximum score (least impact on the environment) is 100 . Products or processes can be evaluated based on their respective numeric scores.

Input-Output Models. A difficulty in estimating the environmental effects of producing a product is selecting a boundary or cut-off point for analysis. That is, in producing product $\mathrm{A}$, for example, machinery is used. The machinery is made from steel, which in turn uses iron ore. Fuels were used to produce the machinery, the steel, and the iron ore. Transportation is used in all phases. When estimating the environmental effects of producing Product A, should both the direct and indirect inputs be used? How do you estimate both the direct and indirect effects?

Input-output models capture the interdependencies between production processes. In inputoutput models, complex economic interactions are captured by proportionality relationships. For example, Lave at al. (1995) used a 519-sector input-output model to estimate the environmental discharges of five products. The input-output model was used to estimate the direct and indirect changes in economic output in the economy as a result of producing the five products. Environmental discharges were estimated by applying the average level of toxic discharges and electricy use to the estimated output changes. Because average discharges of conventional pollutants is not readily available, their analysis was limited to toxic discharges and electricity use.

\subsection{Health Effects}

Estimating the health effects of a process requires a detailed understanding of the stages of the process. For example, in estimating the health effects of producing electricity from coal, five stages may be appropriate: coal mining; coal cleaning, transportation; electricity generation; and electricity transmission and distribution (Oak Ridge National Laboratory and Resources for the Future, 1992). Once the stages are identified, estimating health effects requires an understanding of the hazard, how humans may come into contact with the hazard, and the biological response once they are exposed. Understanding the hazard includes knowing all major effluents, their release rates, and their chemical and physical forms. Effects are typically divided into accidents and health effects. All health effects are not "externalities." Many of them may be "internalized" as a cost of doing business through wage and benefit packages. 
Accidents have been studied to a greater degree than health effects and are, therefore, easier to quantify. Health effects from exposure to emissions have been studied to a lesser degree. Temporal effects are also a complicating problem for health effects. Some types of emissions may not affect people for decades after their release. Over what period of time should the analysis cover?

\subsection{Other External Effects}

\subsubsection{Economic}

If the course of action under consideration--i.e., the purchase or sale of assets--is large enough, the markets in which goods are traded could be affected. That is, the price of the good in regional, national, or international markets could increase or decrease with a corresponding change in quantity produced. For example, if the government held a large fraction of the world reserves of a commodity, selling those reserves may significantly depress the price of the commodity on the world market. An econometric model of the market in question can be estimated to determine the price effects of the sale. Although the effect on world markets may be an important consideration for the government decisionmaker, it is questionable whether this type of effect is an "externality" in the strict economic sense. As discussed in Section 2, many economists consider this effect a "pecuniary externality" and, therefore, would not include it as part of the benefit-cost calculus.

A similar argument pertains to macroeconomic effects such as the creation or loss of jobs as a result of a purchase or sale. Again, as discussed in Section 2, some economists would question using a change in employment in a benefit-cost analysis. They consider changes in employment as transfers from one part of the economy to another. However, if there is unemployment in the economy and the purchase or sale results in a net change in jobs, a strong argument can be made to include the net employment effects.

Irrespective of the conceptual merits of including or excluding employments effects, decisionmakers may want to have that information when making decisions about purchases and sales of assets. Also, employment and income effects are very important when conducting damage assessments using the principles of LCA.

Econometric techniques can be used to quantify macroeconomic interdependencies in an economy. These econometric models incorporate equations for either the expenditure side of an economy (i.e., the consumption, investment, and government expenditures of an economy for a period equal its total output) or the income side of an economy (i.e., the sum of wages, rents, interest, and dividend payments for any period equal total output of the economy for the period). These types of models have been used widely to project macroeconomic effects under different scenarios on a subnational basis or a national basis (Hill, Maddigan, et al., 1987).

Input-output models of the type discussed in the context of estimating environmental effects 
can also be used to estimate macroeconomic effects. These models use proportionality ratios to capture the interindustry effects of macroeconomic activity.

A social accounting matrix (SAM) is an extension of traditional input-output models that can be used to estimate economic activity for LCA analysis (Vogt and Das, 1995). The SAM captures financial flows among major sectors of a regional economy, mapping expenditures for economic actors to their receipts. Inter-industry transactions, expenditures, and revenues for households and the government are major results obtained from using a SAM.

\subsubsection{Socio-Institutional}

A formal framework for estimating socio-institutional impacts does not exist. Oftentimes, these effects depend on the nature of the transaction. For example, analyzing a decision on which of three types of power plants to build (coal, nuclear, gas) will have different effects than analyzing the sale of strategic stockpiles of precious metals.

Two of the most common socio-institutional effects deal with regulation and public acceptance. In fact, even though it is very difficult to quantify these two effects, in many cases they may be the most important considerations in decisionmaking. For example, even though one specific sales option is the most cost-effective, regulations may prohibit the transaction or alter it in such a way that is no longer the most attractive option.

\section{QUANTIFYING VARIABLES}

Ideally, a decisionmaker would be presented with an estimate of the amount of benefits for a specific course of action over the life of the action, along with an estimate of the associated costs. These estimates would be denominated in dollars as present values, using the appropriate discount rate. Comparing the benefits and costs of each option and selecting the option with the highest ratio of benefits to costs results in sound decisionmaking.

Unfortunately, many of the external effects discussed above are oftentimes not readily quantifiable or easily estimable. In fact, as we have seen, there are oftentimes different methodological approaches to estimating the values of these external effects, providing different estimates of their magnitude. Further, it may not be possible to quantify the socio-institutional effects in dollar terms at all. And, in may cases, these socio-institutional effects may be prominent, even show-stoppers for some types of transactions.

Estimates of the values of many of the external effects may not be necessary because the external effects may have already been internalized in the financial cost of the option. For example, the value of health effects may be internalized in cases where the entity insures for health effects or makes investments to accommodate government regulations regarding health effects. 
In some cases, there are no external effects to consider. For example, the external effects of selling an asset where the nature of the transaction is simply a change in ownership--without a change in operating practices--may not include very many external effects. From Figure 1, the social LCA converges with the private analysis in this case. An example of this type of transaction would be the sale of the federal power marketing agencies by DOE to the private sector. Assuming no dramatic change in operations after the sale, the sale of the Naval Petroleum Reserve is another example of a transaction with few external environmental effects.

The values of benefits and costs are generally their market values. For example, the total financial benefits of selling a commodity are the product of the expected quantity of the commodity sold in each year and its estimated market price for the year. This is the case for "market goods," commodities that are bought and sold in markets and for which there is a market price. However, there are also many "non-market goods" that must be considered in LCA. These goods are not traded in markets and, therefore, their value is more difficult to determine.

Many environmental resources are non-market goods. These environmental resources could have a use value. For example, they could be used in recreation. In this case, these resources would be private or mixed, private-public goods. They could also have a non-use value. For example, environmental resources have aesthetic value. In this case, they would be a pure "public good."

Direct and indirect techniques can be used to estimate the value of non-market goods in LCA analysis. Direct techniques involve asking hypothetical questions to consumers on their willingness to pay for environmental resources. Indirect techniques involve observing actual behavior of individuals. Table 1 provides the applicability of measurement techniques to non-market goods.

Direct techniques use surveys to determine how consumers value environmental resources. Contingent valuation is a commonly used direct technique to estimate the value of environmental resources. In this methodology, individuals are asked their willingness to pay for changes in environmental quality. Conjoint analysis is another technique to measure how the population values environmental quality. Originally used in marketing to estimate the market penetration of new products, conjoint analysis uses survey techniques to determine how the population views individual features of a multiattribute choice.

Indirect techniques use revealed preferences to determine the actual behavior of the population toward the environment. Hedonic pricing is a widely used indirect approach to determine how the population values the environment. The basis upon which hedonic pricing rests is that people value commodities because they value the characteristics of the commodities rather than the commodities themselves. For example, an automobile per se does not give people satisfaction. It is the transportation, comfort, safety, and the like that provide satisfaction. Therefore, it is possible to estimate the relationship between the price of a car and these characteristics. 
Table 1

Non-Market Goods and Measurement Techniques

$\begin{array}{cc}\text { Use Value } & \text { Non-Use Value } \\ \text { Technique } & \text { (Private or Mixed Goods) }\end{array}$

Direct

(Survey Methods)

$\mathrm{X}$

$\mathrm{X}$

Indirect

(Revealed Preferences)

$\mathrm{X}$

0

$\mathrm{X}$ indicates an applicable technique

0 indicates the technique is not applicable

\section{THE USE OF LCA IN PRACTICE}

\subsection{Sale of Assets}

In making a decision to dispose of assets, a decisionmaker ideally would choose the most cost-effective way to dispose of the assets. The decision could be complicated by different options to dispose of the assets. For example, making an investment to retrofit could be a possibility. Retrofitting and selling the option could be compared with simply selling the asset outright. In this situation, a decisionmaker would compare the costs of readying the asset for sale with the expected revenues from the sale under the two options. A broader, social analysis may be required, especially if there are environmental, health, and other external effects.

The sale of assets by the United States Department of Energy in its Assets Management Program is an example of a situation where LCA could be an important decisionmaking tool. Under this program, DOE must decide how it will dispose of its assets, many of which are contaminated. LCA is a powerful decisionmaking tool to identify the most cost-effective choice.

For example, LCA was used to determine the most cost-effective way to dispose of the buildings and scrap equipment at the gaseous diffusion facilities at the Oak Ridge Reservation in 
Tennessee (Yuracko, Hadley, and Perlack, 1996). The gaseous diffusion plant was shut down permanently in 1985 when its uranium enrichment services were no longer needed. However, the enrichment facilities and equipment, much of which is contaminated, are still owned by DOE. The problem is to determine the most cost-effective way to dispose of the remaining assets.

In cases other than maintaining the status quo, the remaining equipment must be dismantled, separated, and disassembled. The problem for decisionmakers is to choose among a (1) disposal option in which scrap materials such as compressors, electric motors, piping, and heat exchangers would be disposed of as low-level waste or a (2) recycle option in which portions of the obsolete equipment would be processed and used to make stainless- and carbon-steel boxes. In the analysis, the expected revenues from both options were compared with their costs. Costs include direct financial expenditures and potential environmental and health costs. The local employment and income effects were also considered, along with socio-institutional considerations of both options.

\subsection{Purchase of Assets}

Comparing the cost-effectiveness of purchase or investment options is quite common. Business firms, for example, routinely undertake this type of analysis to rank potential investments. In the case of financial investments such as purchasing stocks or bonds, there are typically no environmental, safety, and other effects because the transactions only involve a change in ownership. For other types of purchases, however, the alternatives have varying degrees of external effects.

A good example of ranking purchase options using the principles of LCA is integrated resource planning (IRP) in the electric power sector (Hill, 1993; Hill, Hirst, and Schweitzer, 1991). Concisely, IRP is a decisionmaking tool that allows electric utilities to compare consistently the costeffectiveness of all their investment alternatives--those on both the demand and supply side--taking into account their different economic and reliability characteristics. The resource options typically available to an electric utility in its planning process are:

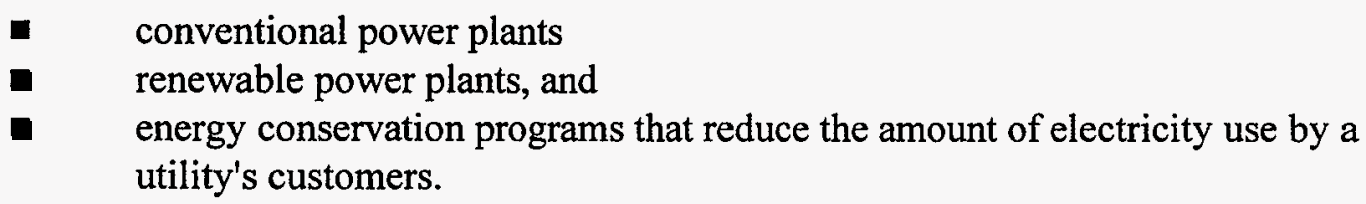

Decisionmakers must choose from among these options considering their implications for the environment, oil imports, and local/regional economies. IRP is currently practiced by electric utilities in more than 30 states. 


\subsection{Damage Assessment}

Although the principles of LCA are most often applied to decisions dealing with the purchase or sale of assets, they can also be used to estimate the effects of natural or man-made disasters on a region. The benefits can be measured as a multiple (i.e., the multiplier effect) of the amount of government and private investment in the region in the aftermath of a disaster. However, in most cases, policymakers are interested in the costs of the disaster. These costs can be environmental, health-related, or economic in nature. 



\section{REFERENCES}

Bjornstad, David J. and James R. Kahn, Editors, 1996, The Contingent Valuation of Environmental Resources: Methodological Issues and Research Needs, Edward Elgar, Brookfield, Vermont.

Electric Power Research Institute, 1991, Technical Assessment Guide: Fundamentals and Methods, Electricity Supply, Volume 3, Revision 6, EPRI TR-100281, Palo Alto, California, December.

Graedel, T.E. and B.R. Allenby, 1995, Industrial Ecology, Prentice Hall, Englewood Cliffs, New Jersey.

Graedel, T.E., B.R. Allenby, and P. R. Comrie, 1995, Matrix Approaches to Abridged Life Cycle Assessment, Environ. Sci. and Technol., Vol. 29, pp. 134A-139A.

Hadley, Stanton W., 1996, ORFIN: An Electric Utility Financial and Production Simulator, Oak Ridge National Laboratory, Oak Ridge, Tennessee, ORNL/CON-430, March.

Hill, Lawrence J., 1993, "Integrating Methods and Resource Selection in Electric-Utility Planning," Utilities Policy, 3(1), pp. 57-61, January.

Hill, Lawrence J. and T. Randall Curlee, 1996, Estimating the Cost-Effectiveness of Government Regulations, Oak Ridge National Laboratory, Oak Ridge, Tennessee, ORNL/TM-13233, Forthcoming.

Hill, Lawrence J., Eric Hirst, and Martin Schweitzer, 1991, Integrating Demand-Side Management Programs into the Resource Plans of U.S. Electric Utilities, Oak Ridge National Laboratory, Oak Ridge, Tennessee, ORNL/CON-311, January (also published by the Electric Power Research Institute, Palo Alto, California, EPRI TR-100255, December 1991.

Hill, Lawrence J., Ruth J. Maddigan, Daniel M. Hamblin, James W. Van Dyke, and Tracy C. Brown), 1987, An Econometric Simulation Model of Income and Electricity Demand in Alaska's Railbelt, 1982-2022, Oak Ridge National Laboratory, Oak Ridge, Tennessee, ORNL/TM-9795, January.

Hirst, Eric, Stan Hadley, and Les Baxter, 1996, Methods to Estimate Stranded Commitments for a Restructuring U.S. Electric Industry, Oak Ridge National Laboratory, Oak Ridge, Tennessee, ORNL/CON-424, January. 
Keoleian, G.A. and D. Menerey, 1994, Sustainable Development by Design: Review of Life Cycle Design and Related Approaches, Journal of the Air and Waste Management Association, Vol. 44, May, pp. 645-668.

Kahn, James R., 1995, The Economic Approach to Environmental and Natural Resources, The Dryden Press, Orlando, Florida.

Lave, Lester B., Elisa Cobas-Flores, Chris T. Hendrickson, and Francis C. McMichael, 1995, "Using Input-Output Analysis to Estimate Economy-Wide Discharges," Environmental Science and Technology, 29(9).

Oak Ridge National Laboratory and Resources for the Future, 1992, 1994, 1995, Fuel Cycle Externalities Reports, 8 Reports, McGraw-Hill/Utility Data Institute, Washington, DC.

Society of Environmental Toxicology and Chemistry, 1991, A Technical Framework for Life-Cycle Assessment, Washington, DC.

Vogt, David Paul and Sujit Das, 1995, "Estimation of Indirect Local Economic Impacts of Alternative Clean-Up Options for K-25," Oak Ridge National Laboratory, Oak Ridge, Tennessee, November, October 30, Draft.

Yuracko, Katherine L., Stanton W. Hadley, and Robert D. Perlack, 1996, Decision Methodology for Fernald Scrap Metal Disposition Alternatives, Oak Ridge National Laboratory, Oak Ridge, Tennessee, November, ORNL-6896. 
INTERNAL DISTRIBUTION

$\begin{array}{ll}1 . & \text { W. H. Albaugh (ORO) } \\ 2 . & \text { J. M. Bird (ORO) } \\ 3 & \text { D. J. Bjornstad } \\ 4 . & \text { R. B. Braid } \\ 5 . & \text { M. A. Brown } \\ 6 . & \text { J. A. Clinard } \\ 7 . & \text { G. E. Courville } \\ 8-57 . & \text { T. R. Curlee } \\ 58 . & \text { S. Das } \\ 59 . & \text { C. E. Easterly } \\ 60 . & \text { J. T. Ensminger } \\ 61 . & \text { S. W. Hadley } \\ 62-111 . & \text { L. J. Hill } \\ 112 . & \text { D. B. Hunsaker } \\ 113 . & \text { R. M. Lee } \\ 114 . & \text { A. S. Loebl }\end{array}$

$\begin{array}{ll}115 . & \text { J. F. Munro } \\ 116 . & \text { R. D. Perlack } \\ 117 . & \text { R. M. Reed } \\ 118 . & \text { D. E. Reichle } \\ 119 . & \text { R. G. Rivera } \\ 120 . & \text { R. B. Shelton } \\ 121 . & \text { W. B. Snyder } \\ 122 . & \text { J. J. Tomlinson } \\ 123 . & \text { D. P. Vogt } \\ 124 . & \text { T. J. Wilbanks } \\ 125 . & \text { K. L. Yuracko } \\ 126 . & \text { ORNL Patent Office } \\ 127 . & \text { Central Research Section } \\ 128 . & \text { Document Reference Section } \\ 129 . & \text { Laboratory Records (RC) }\end{array}$

\section{EXTERNAL DISTRIBUTION}

130. Dr. Thomas E. Drabek, Professor, Department of Sociology, University of Denver, Denver, CO 80208-0209

131. Dr. Stephen G. Hildebrand, Director, Environmental Sciences Division, Oak Ridge National Laboratory, Post Office Box 2008, Oak Ridge, TN 37831-6037

132. Mr. George F. Sowers, P. E., Senior Vice President, Law Companies Group, Inc., 114 Townpark Drive, Suite 250, Kennesaw, GA 30144-5599

133. Dr. C. Michael Walton, Ernest H. Cockrell Centennial Chair in Engineering and Chairman, Department of Civil Engineering, University of Texas at Austin, Austin, TX 78712-1076

134-37. OSTI, U.S. Department of Energy, P. O. Box 62, Oak Ridge, TN 37831

138. ORNL Site Manager, U.S. Department of Energy, Oak Ridge National Laboratory, P. O. Box 2008, Oak Ridge, TN 37831-6269 